\title{
Exposure of Travel Destinations on the Front Covers of the Magazines National Geographic Traveler and Podróże
}

\author{
Anna Jupowicz-Ginalska \\ Faculty of Journalism, Information and Book Studies, University of Warsaw
}

Received 5 May 2018; received in revised form 2 December 2018; accepted 10 December 2018

\begin{abstract}
The article presents the results of the analysis of destinations presented on the front covers of Polish travel magazines: "National Geographic Traveler" and "Podróże". The author accomplished two research goals: firstly, she examined the scale of popularisation of travel destinations in two contexts: the geographical one (division into continents, countries and cities) and the chronological one (investigating changes in popularising particular travel destinations and referring them to the broader political or social context of a given time). Secondly, she indicated the differences or similarities in the selection of the destinations at the macro-level (among magazines, i.e. their editorial policies or affiliation to publishing companies) and at the micro-level (between the main and supporting cover stories).
\end{abstract}

Key Words: magazines' front covers, tourism, travel destinations, National Geographic Traveler, Podróże

JEL Classification: L8, L83, Z32

\section{Introduction and Review of Literature}

Tourism is subject to mediatisation, i.e. "a universal social process (...), meaning the adjustment of activities of various entities to the conditions defined by the specificity of the media's influence" (Oniszczuk, 2011, p. 13). With reference to the tourist sector, it concerns experiences of tourists, mutual influence of real and simulated experiences and the role of tourist 
agencies in creating media messages (Cohen \& Cohen, 2012). Travel journalism, seen as "intersection between information entertainment, journalism and advertising", has an undeniable role in tourism mediatisation (Lizzi, Cantoni \& Inversini, 2011, pp. 356). Its role is growing with the importance of the industry, especially in such aspects as, for example, the study of the sociocultural impact of tourism on society or the analysis of the idea of free time as a social practice (Fursich \& Kavoori, 2001). Analyzing the evolution of travel journalism, Folker Hanusch lists its interdisciplinary dimensions (2010): cultural (presenting foreign cultures); market (the range of information or entertainment presented to recipients); ethical (the impact of PR materials on journalists and on the rules of cooperation with business partners); motivational (critical or approving of tourism).

Dissemination of information, inspiring recipients, valorising tourist products and creating opinions about them are the most important duties of travel journalism, and thus of the media, which carry the effects of journalistic work (Kruczek \& Walas, 2004). Diversified tasks of the media, their ubiquity and influence on recipients make them an important element of tourism, from information policy of its subjects, to opinion formation.

\subsection{The Media against the background of sources of travel information}

The media are one of the sources of travel information. Others, non-media ones, include contacts with friends or family (the so-called word of mouth), advice of tour operators, promotional materials (leaflets, brochures), guidebooks, fairs and exhibitions (Sarma, 2007).

In 2009, Rafał Marek claimed that the Internet will be "the most important source of presentation of tourist offers" (2009, p. 127). These words turned out to be prophetic: today it is "the main communication channel for the tourist sector, as shown by the average number (...) of people seeking information before making a trip" (Drozdowska \& Duda-Seifert, 2016, p. 2). This is confirmed by industry reports: e.g. IAB Polska reports that the Internet is the most useful source of information: behind it are recommendations of friends and family, advertising, television, the press, radio, leaflets, folders and expert statements (2015). This context supports the conclusion of Robert Wolny, who claims that "this is how information is obtained by (...) almost half of respondents using e-tourism services" (2015, p. 413-414). The above data coincide with the global trend indicating the high position of the Internet: Oxford Economics research shows that $63 \%$ of Europeans believe in online news, another $34 \%$ pay attention to travellers' opinions and ratings, $17 \%$ gain knowledge from service providers, and 12\% - from social media 
(Szypuła, 2017).

In view of the above, it can be concluded that the Internet prevails over traditional media (also in terms of broadcasters offering travel content, e.g. blogs, vlogs, social media, portals and specialized vortals). This does not mean, however, that by dominating them, it causes their decline. It should be emphasized that in each of the reports, important sources of knowledge are the recommendations of friends or family and people's own experiences as tourists. The effectiveness of interpersonal contacts in tourism is confirmed by scientific research (Mack Blose \& Pan, 2007), which sometimes questions the direct impact of online content on purchasing decisions. For example, Serena Volo claims that "there is little evidence that the future travel intentions of the readers of these travel blog are significantly influenced by the blog narratives" (2010, p. 12). Also in the IAB Polska report, in the area of effective impact on recipients, the Internet is second only, but the results of traditional media are also significant: for $51 \%$ respondents television is the impulse for shopping, the press for $45 \%$, and radio for $32 \%$ (2015). This means that while the Internet is a popular source of information, other ways of acquiring knowledge turn out to be valuable in the final stages of making decisions. Here it is worth referring to the research from 2014, in which respondents indicated, among others, such sources of travel ideas as recommendations, travel programmes, books, films, the press, recommendations from travel agencies, and advertising in the media (VMG PR, 2014). The Internet was at the end of the list, which was commented: "This shows a clear trend - we want to make individual decisions that meet our needs. We prefer the quality of recommendations over their number - not forums and anonymous opinions, but recommendations of relatives and independent searching for information" (ibid, p. 4).

In the face of a convergent and chaotic communication polyphony, it is optimal for the recipient to use a lot of data. It makes it possible to compare offers, broaden knowledge about selected destinations or check the reliability of published content. The practice of reaching for a combination of information sources (so-called "information search strategies") is common in tourism, and its research has been conducted for many years (Gursoy, 2011).

Such behaviour patterns can also be noticed in Poland, as evidenced by Ingvar Tjøstheim, Iis P. Tussyadiah and Sigrid Oterholm Hoem. According to them, the sources of information which are complementary to the Internet include friends and family, guide books as well as TV and press materials (2007). Traditional media are still an important element of the tourism sector, still playing a significant role in the process of searching for travel information. Among them are TV channels (Discovery, National Geographic), TV programmes (in Poland, for example, "Boso przez świat"), radio programmes ("Reszta świata" in Program I Polskiego Radia SA), sections in 
advice and lifestyle magazines, as well as travel magazines, which focus entirely on getting to know and discovering the world.

\subsection{Printed travel magazines}

Christine A. Vogt and Daniel R. Fesenmaier (1998) claim that the informational needs of tourists are of a functional nature (among listed here are the need for knowledge and the usefulness of the acquired information), innovative (creativity, diversity), aesthetic (fantasising), symbolic (social interactions) and hedonistic (e.g. emotionality, phenomenology).

According to Dale Fodness and Brian Murray, travel magazines play a functional role, i.e. they are used because of the systematically delivered knowledge. Thanks to them, planning a trip is easier: „The use of newspapers and magazines to plan a trip suggests a strategy in which information acquisition occurs on a relatively regular basis irrespective of impending purchase, i.e., ongoing search (1998, p.115). Kathleen L. Abdereck (2007) heads towards hedonism and aesthetics; she stresses that the first motivation is about enjoying the search itself, and the second one is the need to see the place, or, in other words, its visualization. In this way, magazines arouse interest of recipients and make it easier for them to make decisions. Eduardo BritoHenriques (2014, p. 323) also writes about the pleasure resulting from the use of the travel press, recognizing that „many readers (...) merely use magazines as a means to relax and withdraw themselves and to enjoy the pleasure of a disembodied experience of exotic places".

Madelene R. McWha, Warwick Frost, Jennifer Laing and Gary Best emphasize that travel journalists go beyond reporting, since they take up political, social or cultural issues. Thanks to this, they have "a persuasive power to mediate foreign cultures and destinations and could potentially influence their readers' views" (2016, p. 86). They use language means whose task is to engage the recipient and encourage them to experience the journey. Such narrative has "the ability to mentally transport the reader to an imaginary landscape" (ibid., p. 87).

Photographs are an important element of every magazine as well as an effective tourist marketing tool (Farahani et al., 2011). Photographs, and stories accompanying them, influence the readers most strongly. According to Woojin Lee and Kathleen Andereck, they form a general impression of the usefulness of the magazine, which in turn supports the decision-making process of the recipients and at the same time transfers to the image of the magazine as a consultant and sources of information (2010). Arturo Molina and Águeda Esteban write about their role in the informative and decision-making context, claiming that the attractiveness of the place shown in the pictures may encourage and motivate readers to choose a destination or set 
out on a journey (2006). It should be added that the condition for the full impact of images is their coherence with the text, because its lack negatively affects the memorisation and assimilation of content (Hsu \& Song, 2013).

\subsection{The front cover of an illustrated magazine}

One of the most important elements of each magazine is its front cover. It is considered a showcase of the press brand and at the same time a packaging of its content (White, 1982), which has more recipients than the magazine itself (Brzoza, 2016). It strengthens the competitiveness of the title, guarantees its variability (e.g. updated cover stories) and stability (e.g. layout) at the same time. It has the following functions (Jupowicz-Ginalska, 2017a):

a) information and promotional - provides information about the content of the magazine, date, price; it creates the image of people, products and services appearing on it; is the subject and object of promotion (it is part of communication activities in itself);

b) ideological - divided into culture-forming (comments on social, political, cultural, religious phenomena) and educational (inspires to broaden knowledge); According to Sammye Johnson and Carlos A. de Lozano, it refers to current events, thus becoming "a historical artifact" (2002);

c) relational - broken down into communication (builds interaction with the reader through direct phrases and metaphorical formulations) and entertainment (entertains, relaxes);

d) innovative - modernises the magazine, introducing unusual design and technical solutions (e.g. covers enhanced with VR technology);

e) protective - secures the content of the magazine;

f) financial - affects the purchase of the magazine by readers (first it draws the attention of recipients, then encourages to browse the magazine, and finally affects shopping decisions: in other words, the fate of the magazine is largely determined by what will be on its front page).

A particularly important part of front covers are cover stories, which take graphic-text forms and thus represent the content of the whole magazine (Jupowicz-Ginalska, 2017b). They are divided into the main ones, exposed in the most visible way (the largest picture and noticeably separated text) and the supporting ones (based on the text itself or simple graphics, rarely on an additional photo). The role of the main cover story, regarding its size, is to maximally draw attention to the magazine and encourage people to browse through it. 
Supporting stories have a strengthening and complementary function. They can influence recipients' decisions if the impact of the main topic turns out to be insufficient. However, due to smaller graphics and texts and because there are more of them, they require concentration and perceptiveness.

Of course, front covers also consist of other elements. Ben Wasike adds the logo with the name of the magazine (2017), while David E. Sumner and Shirrel Rhoades exchange the tagline, price, barcode, date of issue and website address (2016).

The front cover is important for every participant in the publishing process. Taking on the one hand its importance and interdisciplinarity (it can be analysed, for example, from the media, linguistic, marketing and economic perspective), on the other - the mediatising role of travel magazines in tourism, and on the third - the position of tourism sector, the author decided to combine these three threads and explore the role of the front covers of Polish travel magazines.

\section{Research Methodology, Description of the Research Sample, Objectives and Hypotheses}

The author's goal was to select magazines with a comparable subject and position, while differentiating them due to the genealogy of the brand. Hence, National Geographic Traveler and Podróże were chosen as the subject of the analysis.

The title selection key was based on the following categories:

a) readership level - the titles are the only ones in their thematic category to appear in the summary of the Polish Reading Research $\left(\mathrm{CCS}^{1}\right.$ index for NGT was $1.0 \%$, for Podróże $-1.2 \%^{2}$ );

b) average circulation per issue - in December 2017 for Podróże it was 19,600 copies, for NGT - 29,100 copies (Teleskop.org.pl, 2017);

c) sales of printed editions - in December 2017, for Podróże, it was 6,664 copies, for NGT - 17,293 copies (Teleskop.org.pl, 2017);

d) affiliation to publishing companies - Podróże is published by a Polish group TIME SA, while NGT by Burda Publishing Polska Sp. z o.o. (Podróże is known on the domestic publishing market, whereas NGT in the world, for example due to the brand National Geographic);

e) publishing cycle and subject matter - the magazines are travel monthly magazines,

\footnotetext{
${ }^{1}$ The seasonal cycle readership (CCS) - the percentage of respondents who came across the title at least once during the seasonal cycle of the title (PBC, 2018).

${ }^{2}$ Other magazines, e.g. "Poznaj Świat", were not included in the analysis as they do not appear in the ranking (PBC, 2018).
} 
where:

- NG: Traveler has been published in Poland since 2005 (in the world since 1984), initially as a bimonthly. It is one of 12 national editions of the title. It is addressed to "active people who are curious of the world and its natural, architectural and cultural attractions" (Burdamedia.pl a, 2018). The magazine consists of reportages, tips and "adventure" type of material. Its opinionforming function is emphasized: "Traveler sets travel trends. It indicates unobvious destinations, which become fashionable. Sometimes it creates these trends" (Burdamedia.pl b, 2018, p. 3).

- Podróże has been published since 1998, first as a bimonthly. The publisher puts emphasis on the informative and cognitive values of the magazine, tips and recommendations, targeted at people "looking for inspiration for trips, not only on holiday" (Grupazpr.pl, 2018). The editor-in-chief of the magazine claims: "We want to encourage travel, suggest ideas, solutions, advice (...) Our magazine is for those who organize trips individually, on their own and want to know something about the place they are going to. We try to prepare suggestions for a centralized group of recipients. These trips are neither luxurious nor extreme; they are for everyone." (Kłopotowska, 2015).

The front covers of both magazines available on the publishers' websites were analysed, including the period when they appeared as bimonthlies. In this way:

a) for NGT - from 2006 to the end of 2017, after rejecting unreadable or inaccessible covers, 110 covers were studied (National-geographic, 2018);

b) for Podróże - from 2007 r. do the end of 2017 r., after rejecting unreadable or inaccessible covers, 124 covers were studied (Podroze.se.pl, 2017).

The covers were not totalled up, as each magazine was analysed separately and the analysis categories were the same for both titles.

The main objective of the quantitative analysis (enriched with the qualitative analysis) was to research the scope of exposure of travel destinations through main and support cover stories. The specific objectives of this article were:

a) researching the scale of popularization of travel destinations in a geographical context (division into continents, countries and cities, with reference to other attractions) and a chronological context (in the adopted time interval of the analysis, with reference to 
changes in the popularization of particular directions of travel and their reference to the broader political or social context prevailing at that time);

b) indicating differences or similarities in the selection of the destination at the macrolevel (among magazines, i.e. their editorial policies or affiliation to publishing companies) and at the micro-level (between the main and supporting cover stories).

The specified goals were used to verify the following hypotheses:

H1. The front covers of NGT and Podróże differ in destinations presented in the main and supporting cover stories. It is assumed that Podróże, due to its affiliation to the Polish publisher, will refer to Poland more often, while NGT will refer to exotic directions and extraordinary areas, not necessarily placed in Europe. It means, that if covers are the quintessence of the magazine's editorial policy, it can be assumed, that editorial strategy influences on choosing main and supporting cover stories, therefore support of the touristic destinations.

H2. Magazine covers are "historical artefacts". That is, their content is a reflection of the global political, cultural or economic situation: it is assumed that events in Egypt, Libya or Syria have affected the cover content - these countries were replaced by other, more stable ones, for example in Central and Eastern Europe (so it can be assumed that these events negatively affected the mediatization of tourism of these destinations).

The author decided to submit this paper to the Journal of Tourism and Services due to the common theme between the magazines, the content of the article and the subject of the research presented in the article. As it is written on the magazine's website, Journal "focuses on tourism and service industry development" and is connected with, ,important topics and advance theoretical knowledge or thinking about key areas of tourism and services“. It can be said with certainty that the mediatization of tourism is a part of the above thematic area: after all, the media not only inform about this industry, but also they promote it, support it and help in its development. One of the most important participants in the mediatization of tourism is, of course, tourism media. In this article they are represented by recognized magazines in Poland: National Geographic Traveler and Podróże. In turn, one of the most important elements of each magazine is the front cover, which promotes everything that is on it. In the case of the abovementioned media, these are, e.g., destinations, lifestyle, products and services related to the tourism. Therefore this text, focusing on the analysis of the front covers of two tourism magazines, is an example of studies on the tourism mediatization (in the area of the tourist destination). 


\section{Problem Solution and Results}

The subjects of the main and supporting cover stories were not only continents, countries, cities but also geographical lands. It should be clarified that when for example a country was mentioned on the cover, its continental affiliation was not always mentioned (just like cities were not located in countries). To average the results, the author assigned the directions to their geographical origin. She arranged the obtained results and arranged them chronologically for each of the continent, later she placed them on world maps (for the main stories); for supporting stories, tables were used. Antarctica and the Arctic were omitted in the lists, because the total number of their indications was negligible.

\subsection{Recommended destinations in main cover stories}

3.1.1 Indications of destinations on the covers of NGT in the years 2006 - 2017 - main cover stories

On the basis of Graph 1, it can be stated that currently the most exposed travel destinations are European and Asian locations. The sharp rise in their popularity falls in the years 2011 - 2012. It can be seen that this is a growing trend (apart from declines in 2014).

Graph 1

NGT - the number of indications for each destination promoted on the covers of the magazine in the years $2007-2017$ 


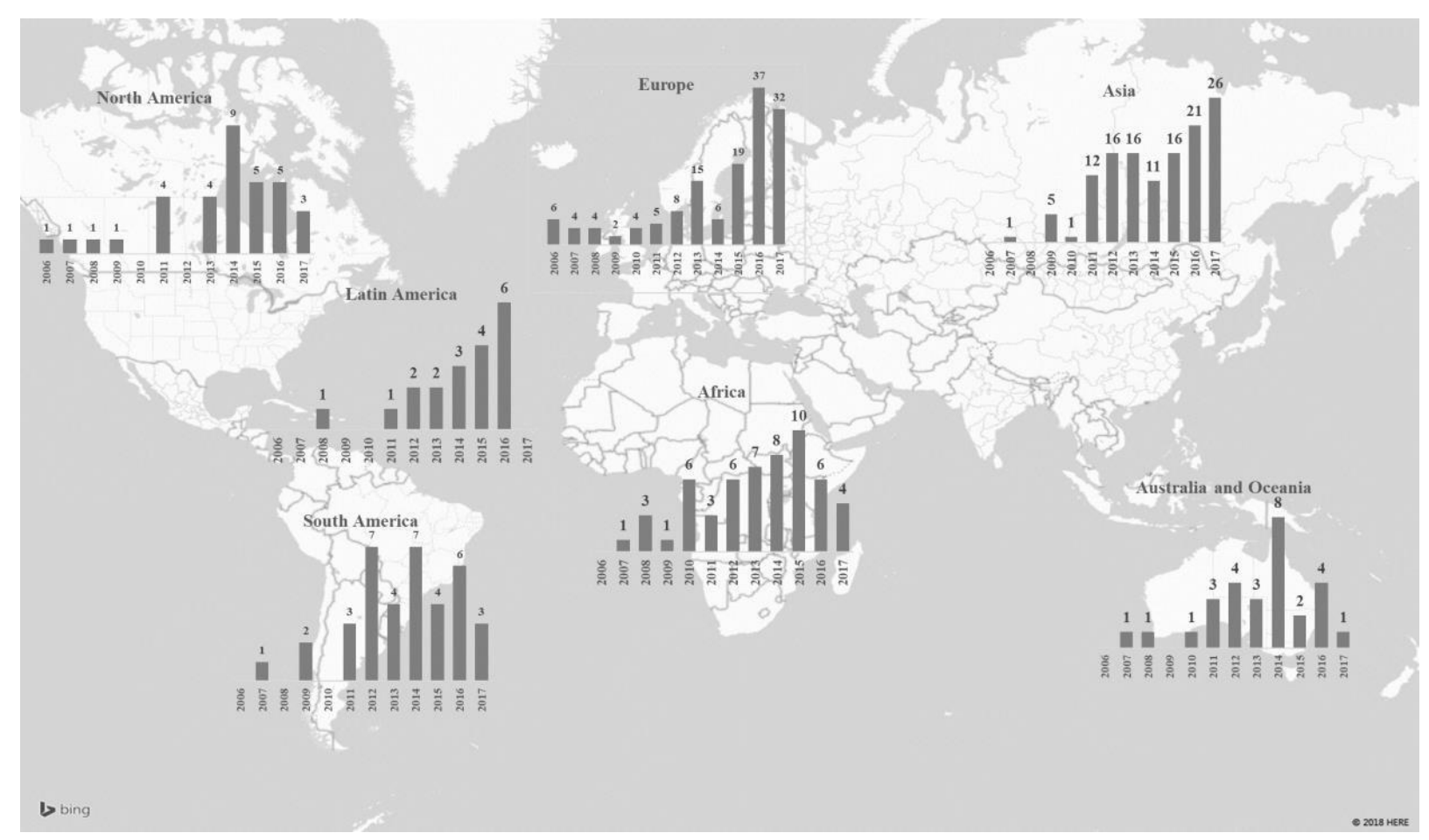

Source: Author (for this study)

As far as Europe is concerned, in recent years there was an increase in interest in the destinations considered as the domain of mass tourism (in the past, they rarely or never appeared in NGT). These destinations are:

a) Italy - in 2008 mentioned once, while from 2012 to 2017 as many as 13 times (including several mentions of Venice, Rome, but also less obvious Bari or Cinque Terre);

b) Spain - in 2006 described twice, while 16 times since 2012 (usually Barcelona and the islands, for example the Canary Islands or Balearic Islands);

c) France - until 2010 it appeared 5 times altogether, and since that time 14 times (mostly as Paris, Provence, or generally as a country);

d) Greece - it was on the cover 10 times since 2013 (as a country, Crete, the Cyclades, Santorini)

e) Croatia - appeared five times since 2011 (as a country rather than attractions)

f) Turkey and Portugal (each of them four times in the years 2012 - 2016).

Recently, NGT more often indicated directions outside the list of "holiday" destinations. These are Albania (twice in recent years, earlier once), Belarus (once in 2017), Bulgaria (once in 2016), the Czech Republic (once in 2017), Iceland (five times in 2014 - 2017), Romania (twice in 2017, earlier once), Ukraine (four times in 2015 - 2017), Germany (four times in 2016 - 
2017, including Berlin and Bavaria) or Hungary (twice in 2015 - 2017). Norway was keenly supported by the magazine (10 publications in total, eight of them since 2011 , usually as a country).

How is Poland presented on this background? In the years 2007 - 2010, three mentions appeared about it, and since 2011 - as many as 10. In this country, the publisher focused on lands (Podlasie, Warmia, Kashubia, Roztocze), less on cities (e.g. Wrocław, Gdańsk, Poznań, Warsaw). Taking into account the number of publications on European countries, it can be concluded that Poland is ranked in the middle in this respect.

Asia, on the other hand, is presented either as a continent or a geographical region, e.g. Borneo or Mekong. There are also non-standard destinations, e.g. Sipadan and Pamir. In this context, Asia was mentioned 13 times (since 2011 seven times). Among the most popular countries on this continent one can indicate:

a) China - altogether is appeared 11 times, and since 2011 - 10 times (Beijing and Hong Kong were the main attractions);

b) India - since 2011 appeared 13 times in the NGT (most often as a country, but there were mentions about Mumbai, Kerala, Rajasthan or Bollywood);

c) Japan - it was mentioned eight times, once before 2011 (usually as a country);

d) Indonesia - since 2011 it appeared seven times, including twice in 2015, 2016 and 2017 (it was mainly exposed as a country, but also Bali);

e) Thailand - it was mentioned six times since 2011;

f) Georgia and Burma - since 2011 they were on the covers of "NGT" five times (as countries);

g) Vietnam, Sri Lanka, Nepal - four times since 2011 times (as countries).

Over the past two years, Kyrgyzstan, Kazakhstan and Uzbekistan were more eagerly exposed. Since 2013, the United Arab Emirates (Dubai, Abu Dhabi), Tibet, Cambodia, Iran and Singapore appeared among destinations. The years 2016 and 2017 are the search for new directions, e.g. Israel (Tel Aviv), Jordan, Colombia (Bogota) and Malaysia (three times).

It can be said that the publisher of NGT attaches greater importance to Central America (this is visible since 2011, before which these directions were mentioned rarely or not at all). What is particularly worth emphasizing is the increase of popularity of Cuba, which appeared in 2008 once, but since 2011 as many as five times (three times as Havana). In 2016, Martinique was shown on the covers twice; The Caribbean also turned out to be equally popular (three times in the abovementioned research period). NGT also encouraged its readers to visit Panama, 
Nicaragua, Honduras and Jamaica.

South America enjoys changeable attention of the editors, although since 2011 the number of cover mentions did not fall below three a year. The most common were: Brazil (six times since 2012, with reference to the country or Rio de Janeiro), Chile (six times, including five times since 2010, with attractions such as Torres del Paine, Valparaiso, Rapa Nui), Peru (six times, in 2016 three times). The continent also appears as a whole: either as South America or Patagonia (six times since 2011). The editors also promote unobvious directions, such as Ecuador, Bolivia, Guatemala and Venezuela (since 2011).

Among the destinations of North America, the leader is the USA, which was mentioned 19 times. The magazine refers to states (California, Alaska), cities (New York, San Francisco, Chicago) and specific attractions (Route 66, Yellowstone). Since 2011, Mexico appeared in the magazine eight times and Canada six times since 2007.

The most popular destinations of Australia and Oceania were Australia (six times since 2013), New Zealand (seven times, since 2013 - six) and French Polynesia (six times since 2011, e.g., the Marquesas Islands, Mangareva, Tahiti). The magazine also showed interest in Papua New Guinea (three times until 2014) and exotic Vanuatu (twice until 2014).

Africa is an interesting case. In 2011, there was a clear decline in interest in this continent. Since 2012, it was slowly being rebuilt, although in 2016 the trend collapsed again. Here, NGT most often mentioned Morocco (in total seven times, but since 2012 six times, most often as a country). Since 2013, South Africa appeared six times (mostly as a country), and Ethiopia - three times (since 2008). Until 2011, references were made to Liberia, Nigeria, Somaliland and Mali; however, since 2011 these countries were not mentioned anymore. In recent years, "NGT" exposed Mauritius (three times), Tanzania (three times, including the Seregenti national park), Tunisia, Seychelles, Senegal, Madagascar, Angola, Benin and Gambia. Egypt, once one of the most frequently chosen directions in the past, appeared in NGT once in 2013 while presenting Alexandria.

\subsubsection{Indications of destinations on the covers of Podróże in 2007 - 2017 - main cover stories}

In the case of Podróże, similar trends can be indicated as in NGT (Graph 2). First, there is a systematic increase in support for European trends. Secondly, Asia is gaining popularity (which did not fall below 5 publications since 2009). 


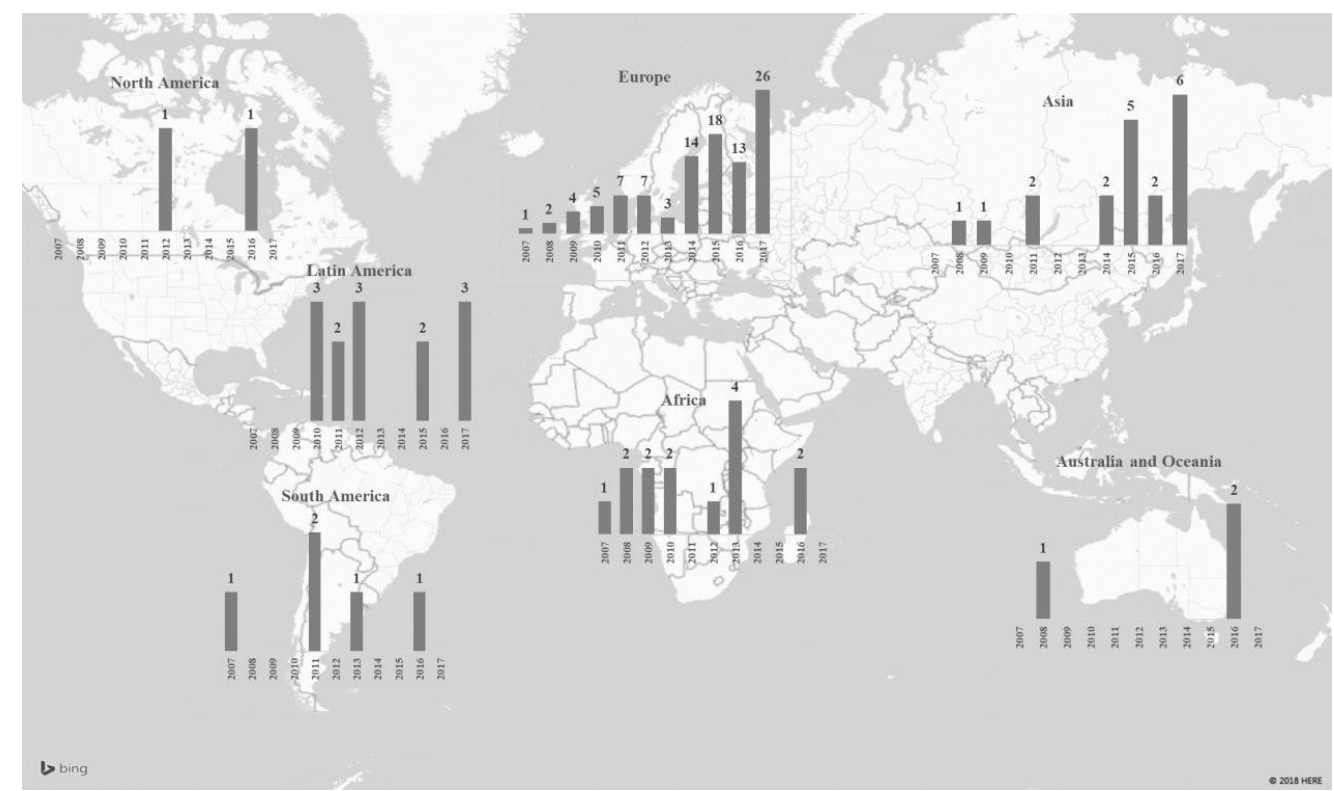

Source: Author (for this study)

The countries that were most often mentioned are:

a) Spain - 28 times since 2010 (in 2010 and 2011, 13 times in total); apart from the country itself, references were made to Andalusia, Madrid, Mallorca, Tenerife and Ibiza, Sierra Nevada, Valencia, La Gomera, and Camargue;

b) Italy - 27 times since 2008 (and e.g. in 2017 as many as five times); here as a destination the whole country was recommended, but also Tuscany, Sicily, Marche, Lake Garda and Pantelleria;

c) Portugal - 20 times since 2008; the biggest attractions were the Algarve, Lisbon, Tejo, the Azores and Porto Santo;

d) Poland - 22 times since 2007 (only in 2016 - 2017 eight times); readers were encouraged to visit the country as such, but also Masuria, the coast, Krakow, Świnoujście, Cieszyn (so you can see that the country was supported willingly and more often than by "NGT");

e) Balkan states - since 2011 Croatia appeared 7 times (as a country, Dubrovnik or Zagreb); Albania and Montenegro 3 times; Macedonia and Bosnia and Herzegovina twice; Serbia once (it is worth adding that some countries received support since 2015, although the Balkans were described as a land since 2012, six times so far).

Destinations such as Greece, France and Turkey were less popular. Since 2009 Hellas appeared on eight covers; France had 10 exposures since 2010 (mainly Paris, Provence and Corsica), and the European part of Turkey - four since 2011 (the Asian part was mentioned five 
times in years 2012 - 2013). The United Kingdom was in no better situation (five times since 2012, with the promotion of London and Scotland), Cyprus (three times since 2015), the Netherlands and Denmark (twice).

The last three years of research is marked with the growing support for Poland's neighbours: the Czech Republic (twice in 2017, with the previous reference to this country from 2012), Germany (eight times since 2012, most often in the context of Berlin); Belarus (in 2017), Lithuania (in 2014) and Slovakia, which was on the cover of Podróże six times.

Since 2015, the magazine systematically referred to Austria, and more recently to Romania, Iceland, Norway, Switzerland, Hungary (mainly Budapest), Sweden and Slovenia (this country regained the magazine's interest in 2015) Thus, it can be seen that the publisher is looking for new destinations and trying to differentiate the content of the main cover stories.

As for Asia, there was an increase in interest in Indonesia (in total seven times, and in 2016 four times; Bali and Java were exposed); China (eight times since 2007, mainly in the context of Shanghai and Hong Kong). To a lesser extent, in recent years, Thailand was referred to (four times since 2011), India (since 2013 three times), Laos (twice), Tibet and Vietnam (each country once since 2011). In the last three years, the publisher also pointed to Taiwan, Nepal, Japan and South Korea.

The situation of Africa is interesting: here too, 2011 was a breakdown of support for this continent. The exception is 2013, when Africa tried to rebuild its presence on the covers; however, as proven in subsequent years, it was not very effective. As an attraction, the Nile appeared, not affiliated to any country (three times until 2010), the Sahara and the savannah. The countries which are worth pointing to are Tunisia and Morocco (three times each, with the trend disappearing since 2013), Tanzania (twice, together with Djerba and Zanzibar) and once: South Africa, Kenya, Ethiopia and Mauritius.

In Central America, the places which were promoted most were Cuba (since 2010), the Caribbean and the Dominican Republic (each four times during the entire research period) and Jamaica. South America is Peru (twice since 2011) and Argentina (Buenos Aires). Considering North America, it was most encouraged to visit Mexico (three times) and the US (five times since 2007, with the emphasis on Florida, California and New York).

Australia and Oceania were presented as islands (the Cook Islands, Papua New Guinea and, generally, the Pacific Islands). It should be noted that for this continent (as well as for the Americas) it is difficult to indicate unambiguous trends due to the small number of publications. It can be concluded that in recent years Latin American or North American destinations were more often presented, but this is assumption needs to be made carefully and requires verification 
in the future.

\subsection{Recommended destinations in supporting cover stories}

\subsubsection{Indications of destinations on the cover of NGT in years 2007 - 2017 - supporting cover stories}

On the covers of NGT a total of 828 supporting stories appeared (in some editions their number reached even $10-14$ threads). As can be seen in Table 1, Europe and Asia generated the greatest interest; Africa was in the third place. The remaining continents were less frequent on the front pages (a small upward trend can be observed only for North America).

Supporting stories in "NGT" years 2006 - 2017 (percentage distribution)

\begin{tabular}{|c|c|c|c|c|c|c|c|}
\hline year & Africa & $\begin{array}{c}\text { South } \\
\text { America }\end{array}$ & $\begin{array}{c}\text { North } \\
\text { America }\end{array}$ & $\begin{array}{c}\text { Latin } \\
\text { America }\end{array}$ & $\begin{array}{c}\text { Australia } \\
\text { and Oceania }\end{array}$ & Asia & Europe \\
\hline $\mathbf{2 0 0 6}$ & $13 \%$ & $10 \%$ & $3 \%$ & $0 \%$ & $3 \%$ & $23 \%$ & $47 \%$ \\
\hline $\mathbf{2 0 0 7}$ & $0 \%$ & $25 \%$ & $25 \%$ & $0 \%$ & $0 \%$ & $0 \%$ & $50 \%$ \\
\hline $\mathbf{2 0 0 8}$ & $4 \%$ & $0 \%$ & $4 \%$ & $0 \%$ & $4 \%$ & $21 \%$ & $68 \%$ \\
\hline $\mathbf{2 0 0 9}$ & $17 \%$ & $3 \%$ & $3 \%$ & $0 \%$ & $6 \%$ & $25 \%$ & $47 \%$ \\
\hline $\mathbf{2 0 1 0}$ & $14 \%$ & $9 \%$ & $9 \%$ & $7 \%$ & $2 \%$ & $33 \%$ & $26 \%$ \\
\hline $\mathbf{2 0 1 1}$ & $8 \%$ & $3 \%$ & $5 \%$ & $2 \%$ & $7 \%$ & $22 \%$ & $53 \%$ \\
\hline $\mathbf{2 0 1 2}$ & $19 \%$ & $5 \%$ & $5 \%$ & $2 \%$ & $4 \%$ & $14 \%$ & $51 \%$ \\
\hline $\mathbf{2 0 1 3}$ & $23 \%$ & $8 \%$ & $5 \%$ & $0 \%$ & $3 \%$ & $26 \%$ & $34 \%$ \\
\hline $\mathbf{2 0 1 4}$ & $13 \%$ & $0 \%$ & $8 \%$ & $0 \%$ & $2 \%$ & $29 \%$ & $48 \%$ \\
\hline $\mathbf{2 0 1 5}$ & $11 \%$ & $18 \%$ & $5 \%$ & $5 \%$ & $0 \%$ & $32 \%$ & $29 \%$ \\
\hline $\mathbf{2 0 1 6}$ & $15 \%$ & $12 \%$ & $2 \%$ & $2 \%$ & $2 \%$ & $32 \%$ & $34 \%$ \\
\hline $\mathbf{2 0 1 7}$ & $8 \%$ & $6 \%$ & $10 \%$ & $6 \%$ & $0 \%$ & $16 \%$ & $53 \%$ \\
\hline
\end{tabular}

Source: Author (for this study)

The Old Continent was most often written about, although over the years its dominance was diversified. It was particularly popular in 2006 - 2009, 2011 - 2012, 2014 and 2017 (in each of these cases, a minimum of $50 \%$ of the analysed content was devoted to Europe). Among the most popular destinations were, among others:

a) Poland - 53 publications, which gives the country priority in the ranking (up to 2010, there were 13 references, and since 2011, Poland was described several times a year, 
e.g. seven times in 2017); the articles promoted cities (Gdańsk, Gdynia, Zakopane, Poznań, Wrocław, Toruń) and geographical areas (Mazowsze, Masuria, Kashubia, the Bieszczady, Roztocze and the Tatras);

b) Italy - 19 publications, including as many as three in 2017, 2013 or 2011; obvious destinations such as Tuscany and Sardinia were presented as attractions, but there were also references to Siena and the Aeolian Islands;

c) Spain - 14 publications mainly with Barcelona, Andalusia, Malaga and Porto;

d) Great Britain - 12 publications (nine of them since 2012); mainly of London and Scotland, although Bristol and Cornwall also appeared;

e) France - 11 publications, mainly since 2011 (Paris, mentioned four times, should be considered the main destination, as well as Costa Rica).

The remaining European countries received support in the range of $5-10$ publications during the analysed period, with the majority of publications appearing since 2011. These countries are, among others: Cyprus, Portugal (as a country or Lisbon), Germany (Berlin, but also Alsace), Greece (as a country and Greek islands), Sweden (as a country, Stockholm, Bornholm), Hungary (e.g. Budapest) or Austria (Vienna, Carinthia and Innsbruck). It can be seen, therefore, that the authors tried to diversify trends associated with mass tourism and to present in an unusual way, finding places less known to the public.

NGT also reached for extraordinary destinations, such as, for example, Andorra, Luxembourg, Estonia, Latvia and Iceland. And while the first countries occurred sporadically, Iceland was on the pages of NGT several times (five times since 2011).

Again, Russia was scarcely presented (as Petersburg or Moscow) and so were Polish neighbours (until 2014, there were single mentions of Slovakia, the Czech Republic, Ukraine and Belarus). Romania, Malta, the European part of Turkey and Croatia were not popular, either.

Therefore, it can be concluded that, in addition to repeating trends from the main cover stories, NGT treats supporting stories as a complement (i.e., what was intensively exploited in the main stories, can be found to a lesser extent in supporting stories, such as the examples of Norway, Denmark or The Netherlands).

Among Asian destinations, the leading ones were: the Asian part of Russia (13 times, mainly as Siberia, the Kuril Islands and Lake Baikal); Indonesia (eight times since 2010, as a country, Borneo or the Maluku Islands); Japan (from 2011 seven times); China (in total seven times, but in 2017 it appeared twice, most often as Shanghai) and the Asian part of Turkey (with Cappadocia on top). Popular destinations such as Thailand, India, Israel, Georgia, United Arab 
Emirates (mainly with Dubai), appeared long ago and with occasional mentions in 2015 or 2016. In return, the monthly reached, for example, for Uzbekistan, Oman, Pakistan, Yemen, Laos, Lebanon (in 2010), Kuwait (in 2008), Qatar (in 2011), Afghanistan (twice in 2010 and 2012), Armenia (2010), Jordan (in 2011 and 2015). While these countries were mentioned sporadically, Iran was written about five times (also in recent years, mainly in the context of the country, but also Isfahan and Persia), and Cambodia - four times (mainly due to Angkor Wat).

Africa is the third most popular continent in the ranking. In addition to recognizable travel destinations, such as Morocco (mentioned seven times), South Africa (six times) or Kenya (four times), non-standard places were promoted in "NGT", such as Ethiopia and South Sudan (each country five times since 2011) and occasionally Mauritania, Uganda, Cameroon, Botswana or Tanzania. It is worth noting that before 2010 the covers also mentioned Syria, Niger, Rwanda, Gabon and Egypt. None of these countries appeared on the front page of "NGT" anymore. Africa was also portrayed in the context of geographical areas, such as the Sahara (three times) and the whole continent (six times). The Atlas mountains and the Zambezi river were presented as attractions.

Although none of the Americas threatened the position of the abovementioned continents, it is worth discussing them briefly. As far as South America is concerned, in recent years, Argentina and Peru (four times), Colombia, Brazil and Bolivia (three times each) were mostly described. Geographical regions were also exposed, e.g. Patagonia, Amazonia and Andes (three times each). In North America, the USA was dominant: the country was referred to in more than $50 \%$ of supporting cover stories, usually in the context of states (Alaska, Utah, Nevada, Missouri) and cities (Chicago, San Francisco, Washington, New York, which was written about four times). Canada was mentioned less frequently (five times since 2011) and Mexico was described three times. Latin America was on the covers of NGT since 2010, and it was intensively promoted in 2017 (four times). Since 2015, Cuba, Belize and Jamaica were systematically exposed.

Australia and Oceania were dominated by Australia. Papua New Guinea and New Zealand ranked second. Mentions were made of Samoa and Hawaii.

\subsubsection{Indications of destinations on the cover of Podróże in years 2007 - 2017 - supporting cover stories}

The total number of supporting stories amounted to 692. From the second half of 2014, no more than five topics appeared in each issue. In earlier years, usually the number of threads 
fluctuated between five and eight.

Like the main cover stories, the supporting ones in Podróże focused primarily on Europe and Asia (Table 2).

Table 2

Supporting cover stories in "Podróże", years 2007 - 2017 (percentage distribution)

\begin{tabular}{|c|c|c|c|c|c|c|c|}
\hline year & Africa & $\begin{array}{c}\text { South } \\
\text { America }\end{array}$ & $\begin{array}{c}\text { North } \\
\text { America }\end{array}$ & $\begin{array}{c}\text { Latin } \\
\text { America }\end{array}$ & $\begin{array}{c}\text { Australia } \\
\text { and Oceania }\end{array}$ & Asia & Europe \\
\hline $\mathbf{2 0 0 7}$ & $11 \%$ & $0 \%$ & $2 \%$ & $0 \%$ & $4 \%$ & $18 \%$ & $64 \%$ \\
\hline $\mathbf{2 0 0 8}$ & $9 \%$ & $4 \%$ & $0 \%$ & $2 \%$ & $2 \%$ & $27 \%$ & $57 \%$ \\
\hline $\mathbf{2 0 0 9}$ & $15 \%$ & $4 \%$ & $8 \%$ & $1 \%$ & $3 \%$ & $20 \%$ & $48 \%$ \\
\hline $\mathbf{2 0 1 0}$ & $6 \%$ & $3 \%$ & $5 \%$ & $1 \%$ & $0 \%$ & $21 \%$ & $64 \%$ \\
\hline $\mathbf{2 0 1 1}$ & $7 \%$ & $1 \%$ & $7 \%$ & $1 \%$ & $3 \%$ & $22 \%$ & $59 \%$ \\
\hline $\mathbf{2 0 1 2}$ & $10 \%$ & $7 \%$ & $6 \%$ & $1 \%$ & $0 \%$ & $24 \%$ & $52 \%$ \\
\hline $\mathbf{2 0 1 3}$ & $5 \%$ & $5 \%$ & $2 \%$ & $0 \%$ & $0 \%$ & $34 \%$ & $53 \%$ \\
\hline $\mathbf{2 0 1 4}$ & $7 \%$ & $11 \%$ & $7 \%$ & $2 \%$ & $0 \%$ & $19 \%$ & $54 \%$ \\
\hline $\mathbf{2 0 1 5}$ & $0 \%$ & $8 \%$ & $6 \%$ & $4 \%$ & $4 \%$ & $22 \%$ & $56 \%$ \\
\hline $\mathbf{2 0 1 6}$ & $3 \%$ & $12 \%$ & $3 \%$ & $2 \%$ & $0 \%$ & $26 \%$ & $53 \%$ \\
\hline $\mathbf{2 0 1 7}$ & $9 \%$ & $7 \%$ & $6 \%$ & $4 \%$ & $4 \%$ & $17 \%$ & $54 \%$ \\
\hline
\end{tabular}

Source: Author (for this study)

Since 2010, interest in Africa was decreasing (attempts to rebuild its popularity appeared in 2017), but since 2012 there was more support for South America. The other continents appeared less frequently.

As far as Europe is concerned, it is worth noting that in the entire research period the percentage share of publications on it dropped below $50 \%$ only once (48\% in 2009). In the remaining years, it was mentioned very often (even 64\% of all references in 2009 and 2010). The most popular destinations include:

a) Poland - it was written about 97 times, most frequently in 2010 - 2013 (over ten times) and in 2016 - 2017 (nine times); mainly about cities (Lublin, Warsaw, Tricity, Poznań, Wrocław and Szczecin), resorts (Szczyrk, Ustroń, Szklarska Poręba, Supraśl, Jastarnia) and the lands (the Tatras and Podhale, the Beskids, Kashubia, Bieszczady, Warmia and Pomerania); there were also unusual destinations, e.g. Rudawy Janowickie and the Milicz Ponds;

b) Spain - 37 publications appeared about it, mainly in the context of the country, cities (Madrid, Barcelona, Seville), islands (the Canary Islands, Tenerife, Minorca) and geographical areas (Costa del Sol, Costa Blanca); it is worth adding that while before 2011 the publisher referred to unobvious destinations, such as Salamanca, La Gomera, recognizable places were of more interest later;

c) Italy - 24 publications were published, including 15 since 2011 (as many as three in 2017), with the greatest emphasis on the country, Rome, Florence, Venice, Sardinia 
and Como (Trento was the only unusual destination);

d) France - described 17 times, most of it was published until 2011, and since then only occasionally was the country on the pages of "Podróże" (as Paris and Provence, although there were also Burgundy, the Loire Valley or Marseille);

e) Great Britain - mentioned 14 times, nearly $70 \%$ of which were published since 2011 (mainly London, and to a lesser extent - Edinburgh and Manchester);

f) Greece - 13 publications appeared about this country, most of them appeared after 2011; they mostly encouraged the readers to visit the islands of Cyclades, Crete and Rhodes;

g) Portugal - 11 publications were published on it since 2010, in the context of the country, Lisbon, Porto, but also Sintra or the coast of Algarve;

h) Austria - 11 publications after 2010 (as a country);

i) Switzerland - 10 publications, eight after 2010 (mainly Geneva, Lucerne, and Zurich).

Podróże, more often than its competitor, refers to Polish neighbours: Germany (17 times, mostly since 2011; the most indications were on Berlin, but also Rügen, Munich, Dresden and Salzburg); Slovakia (eight times), the Czech Republic (seven times with Prague as the highlight), Lithuania (four times in the context of Vilnius), Ukraine (three times, including Lviv) and Belarus in 2014.

Two threads are worth mentioning: first, the tendency to present Europe in a less standard way (e.g. Serbia in 2016, Lapland after 2013, Kosovo in 2011 and 2014, three times Macedonia, Monaco in 2010, Andorra in 2010, Bosnia and Herzegovina in 2016). Secondly, some of the directions, which are considered as mass ones, do not appear in the magazine as often as one would expect; Croatia has been referred to six times (after 2010), Cyprus - three times (after 2011), and Malta three times (since 2014).

Scandinavian countries are very popular, mainly Norway (eight times since 2010), Sweden (six times since 2010, mainly as Stockholm), Denmark (four times as Copenhagen) and Finland (twice). There was almost no mention of the European part of Russia; Estonia, Bulgaria, the Netherlands and Ireland were described more often.

As part of supporting cover stories, Podróże also promote the Asian continent. This support has a different range, but never falls below $15 \%$ of all mentions in a given year. The most-mentioned countries include:

a) India - the country was written about 12 times, with the focus on the country and 
Goa (Kerala also appeared);

b) Indonesia - obtained 11 publications (most of them since 2013); in addition to the country, Bali and Borneo were referred to;

c) China - they appeared on the covers ten times in the analysed research area, mainly since 2011 (in the form of the country, not selected attractions);

d) the Asian part of Russia - before 2014 it was described 11 times (e.g. about the Lake Baikal, Siberia, Yakutsk): since that time no cover mentions were made about it;

e) Japan - out of 10 publications, nine appeared since 2010 (as a country).

Since 2011, Georgia became more and more popular; it was described eight times already (usually in the context of the country, although Batumi, Abkhazia and Tbilisi were also mentioned). Sri Lanka (six times), Vietnam, the Philippines and Israel (five times each), the United Arab Emirates and Cambodia (four times each) were in a similar situation. In the last two years, countries such as Mongolia, Qatar, Iran, Bhutan, Kyrgyzstan, Uzbekistan and Singapore were also noticed. On the other hand, Afghanistan, Jordan, Laos, the Maldives, Pakistan, Taiwan and Syria were abandoned (no publications since 2013, although they had been mentioned several times earlier).

Table 2 shows that Africa did not maintain its growing support from the years 2007 2009, losing it in 2010 and 2011. Since then, the percentage share of publications on the continent has not exceeded 10\%. Most often described countries were: Morocco (nine times until 2014), Kenya and Tunisia (four times till 2014), Namibia (three times till 2014). It should be noted that Egypt appeared five times in the years 2008 - 2010, while since 2011 there was not a single publication. It is worth noting that in 2016 and 2017 new destinations appeared on the covers of Podróże, such as Madagascar, Angola, Mozambique, and Zambia.

Among the countries of South America, Brazil was referred to (eight times since 2009, with almost equal division between Rio de Janeiro and the country as such). In the last three years, Bolivia (three publications in total) and Colombia (twice in 2017) aroused interest. Paraguay and Uruguay should also be mentioned, as these are new destinations that did not appear before. Other countries were written about with varying frequency, some returned to the cover after many years, such as Peru, Guatemala and Chile. In North America, the most popular is the USA, which was described 22 times. These publications were dominated by New York (ten stories, including two in 2017), followed by Los Angeles, Las Vegas, Miami and New Orleans. The states (California, Alaska) and attractions (Grand Canyon) were also promoted. Podróże also encouraged its readers to visit Mexico (seven times) and Canada (twice). In Central 
America, in the years 2015 - 2017, reference was made to Cuba, Nicaragua, the Caribbean and Belize.

In Australia and Oceania, Australia has received support (seven times since 2009: as a country, Sydney, Melbourne and Christmas Island) and New Zealand (three times). Other destinations, such as Papua New Guinea and Tuvalu, were mentioned sporadically.

\section{Conclusions}

The author accomplished the defined research objectives, proving that tourism is an object of mediatisation. At the same time, however, it fits in and responds to globally important events, thus affecting the content of travel magazines and their covers. Going further, the author examined the scope of popularized travel destinations in the geographical and chronological context, which simultaneously led to showing the scale of differences and similarities between magazines, and also enabled the verification of the hypotheses.

The main cover stories of both NGT and Podróże primarily supported Europe and Asia, Africa appeared in third place, while the remaining continents were outside the podium (at the bottom of the list were Australia and Oceania as well as Arctic and Antarctica, analysed together). In general terms, there is a correlation: supporting stories usually strengthened the trends determined by the main stories, primarily by increasing and diversifying the number of destinations in a given area. Thus, it can be concluded that the messages formulated on the covers, received comprehensively by the readers, were consistent.

The years 2010 - 2011 were particularly important in the context of the chronology and its impact on the exposure of destinations in both titles and types of cover stories. As the analysis showed, at that time the number of indications for Africa decreased markedly, while it increased for Europe and Asia (in the case of NGT also for Central and South America). After several years of stagnation, Africa came back to the magazines, but with less frequency and with the exception of several countries that had been mentioned earlier. It is necessary to explain what should be combined with this fact. The indicated years are the period of the so-called Arab Spring, when massive protests against the rulers went through some parts of Asia Minor and North Africa. The population protested against the deteriorating financial situation, corruption of the authorities, restricting civil liberties, social inequality and nepotism. Demonstrations took various forms, from initially peaceful speeches, through acts of suicide death, to riots, takeovers and civil war. The world was particularly interested in the revolution in Tunisia (the overthrow of the rule of Zayn al-Abidin ibn Ali in 2011), Egypt (the overthrow of Hosni Mubarak's rule in 
2011), Libya (the overthrow and the death of Muammar Gaddafi and the civil war in 2011). The Arab Spring swept with no less force through Algeria and Bahrain; there were also protests in Jordan, Yemen, Lebanon, Morocco, Oman, Saudi Arabia, Kuwait, and Mauritania. Demonstrations in Syria were bloodily suppressed, which led to the escalation of violence and became one of the causes of the ongoing civil war. The tragic events of the beginning of the decade had a negative impact on the whole tourist sector of that region. The countries which had previously been popular among travellers (Egypt, Syria, Tunisia) started to be considered dangerous. Józef Sala wrote about the close relationship between geopolitical conditions and tourism, claiming that "for the sake of their own health and safety, tourists prefer trips to politically stabilised countries" and "the development of domestic and international tourism is heavily dependent on political stability of countries and regions" (Sala J., 2012, p. 15). This approach is reflected in the analysed covers of travel magazines: while these countries quite often appeared in magazines until 2009, then there was a marked breakdown in their promotion. The countries where the situation became stable or where the riots were minor (e.g. Morocco, Tunisia, United Arab Emirates) came back to the covers first, but this happened not earlier than 2013. It should be noted that Egypt has not yet restored its media position, let alone Syria.

Thus, the Arab Spring contributed to changes in the destinations displayed on the covers of both magazines. It can be simply stated that Asian countries benefited from it. For example, in 2017, the Polish were more and more keen on travelling to the countries of Southeast Asia, with Thailand and the Philippines being the most popular (alepod, 2018). This choice was justified by the fact that in both countries "you can be sure of beautiful sunny weather and low cost of stay, which undoubtedly allows you to enjoy greater pleasure of traveling" (EA, 2018); however, stable political situation was certainly an important factor influencing travel decisions. As proved by the analysis, both countries appeared on the covers since 2011 much more often than before the Arab Spring (like, for example, Japan, Sri Lanka and India).

In the context of the exceptional growth of popularity of some countries, one ought to mention the People's Republic of China, which in 2015 - 2017 (especially 2017) systematically appeared both in Podróże and in NGT. On the one hand, this can be considered a manifestation of the intense global economic and PR campaign of this country, and on the other hand it might be the effect of the cooperation agreement on tourism, signed by Poland and China in May 2017 (Aktualnosciturystyczne.pl, 2017). Another meaningful factor is the fact that 2018 was declared the EU China Tourism Year.

Europe also benefited from the Arab Spring. Admittedly, this direction was recommended even before the events of 2010 - 2011, but after this time the frequency of 
recommendations increased significantly (especially in Podróże, which even more strongly turned to the Old Continent.) It is not a great surprise that in both magazines obvious destinations were very popular, such as Spain, Italy, and Portugal. These countries can be described as "safe bets", which were additionally strengthened with less popular recommendations (not only Rome, Madrid and Lisbon, but also the Aeolian Islands, Segovia and Sintra). There was also a growing interest in Scandinavia - mainly Norway and Iceland.

The above relations between political and social events and the number of mentions of countries on cover pages may, in the author's opinion, be taken as confirmation of the second hypothesis $(\mathrm{H} 2)$, according to which the front sides are "historical artefacts" reflecting the current political, cultural or economic situation.

Taking first hypothesis (H1) into consideration, the author confirms the incompleteness of this assumption. On the one hand it is correct (in the area of statement "the front covers of NGT and Podróże differ in destinations presented in the main and supporting cover stories. It is assumed that Podróże, due to its affiliation to the Polish publisher, will refer to Poland more often, while NGT will refer to exotic directions and extraordinary areas, not necessarily placed in Europe). For example Poland was on the pages of NGT and Podróże as the main story, with the latter magazine referring to it slightly more often. A huge difference can be seen in supporting stories: in Podróże Poland dominated all other destinations, which did not take place on such a scale in National Geographic Traveler. The magazines also approached Poland's nearest neighbours in different ways (except Germany, which was mentioned in both of them); Podróże was more willing to refer to Slovakia, the Czech Republic and Lithuania than its competitor. Ukraine was described comprehensively (NGT more as the main story, while Podróże as the supporting one), excluding the years 2013 - 2014, which in turn can be explained by the geopolitical situation of the region, including the Euromaidan and annexing Crimea by Russia (which can also be referred to the third hypothesis).

The years of 2010 and 2011 also influenced the popularisation of South America and Latin America by NGT (Podróże wrote about them less frequently, focusing on Asian and European destinations). It is worth noting that for both titles quite obvious destinations over the years were Brazil, Argentina, Chile and Peru. In 2015 - 2017, Cuba joined them (with Havana as the highlight), which in turn should be analysed in the broader context of the resumption of diplomatic relations between that country and the United States at the end of 2014 (this is yet another positive verification of the third hypothesis). NGT also mentioned North America and Australia and Oceania much more often, both in the main and supporting stories, (the latter seldom appeared in Podróże). So as for the choice of destinations and the frequency of 
mentioning them, it can be said that despite many common points in displaying destinations, it is clear that "NGT" more readily refers to further and less standard places, while Podróże reach for Europe or tried and tested Asian destinations. This difference can be seen in the approach to Poland, which was more often presented in Podróże than NGT (although, contrary to the author's expectations, Poland quite systematically appeared on the pages of this magazine). Perhaps one of the reasons for the greater diversification of travel destinations in NGT is the globality of this brand, which, like a citizen of the world, encourages its readers to follow the routes which are less taken and inaccessible to the average tourist. Podróże as a Polish brand promotes more willingly not only Poland, but also its closest (Slavic) neighbours.

On the other hand, as mentioned above, there is the incompleteness of the assumption in H1 (in the area of statement, "it can be assumed, that editorial strategy influences on choosing main and supporting cover stories, therefore support of the touristic destinations"). Of course it can also be cautiously concluded that the selection of destinations displayed on the front covers of magazines is related to their editorial policy and at the same time is the way to achieve it. As mentioned, NGT wants to create trends and point out unobvious destinations. Podróże seem to turn to a centralised group of consumers who do not fancy exclusiveness and extremes. It should probably be linked to the fact that travel destinations, such as Australia and Oceania or South Sudan, were more often stories of NGT while Podróże, even referring to exotic countries, reached for popular Thailand and India. The author, however, thinks that not only the covers, but also the content of articles or communication activities for the brand are responsible for the implementation of the magazine's editorial policy. Thus, full confirmation of the first hypothesis (H1) would require examination of the content of all magazines, not just their covers.

\section{References}

Abdereck, K.L. (2016). Use of a travel magazine as a tourism information source. Tourism Travel and Research Association: Advancing Tourism Research Globally. 39. http://scholarworks.umass.edu/ttra/2007/Presented_Papers/39

Aktualnosciturystyczne.pl (2017). Polska podpisała z Chinami umowę o współpracy w dziedzinie turystyki. Retrieved from: https://www.aktualnosciturystyczne.pl/pot/polskapodpisala-z-chinami-umowe-o-wspolpracy-w-dziedzinie-turystyki

Alepod (2018). Gdzie najlepiej wyjechać na ferie? Oto najpopularniejsze kierunki zimowych podróży. Polacy szczególnie pokochali jeden region. Gazeta.pl. Retrieved from: http://podroze.gazeta.pl/podroze/56,114158,22854966,gdzie-najlepiej-wyjechac-na-ferie-otonajpopularniejsze-kierunki.html

Farahani, B.M., Mohamed, B. \& Mat Som, A.P. (2011). Photograph, Information Search and 
Brito-Henriques, E. (2014). Visual tourism and post-colonialism: imaginative geographies of Africa in a Portuguese travel magazine. Journal of Tourism and Cultural Change, vol. 12(no. 4), pp. 320-334. https://doi.org/10.1080/14766825.2014.887722

Brzoza, K. (2016). Człowiek na okładkach wybranych polskich tygodników w 2015 roku. Rocznik Prasoznawczy, vol. X, pp. 139-158.

Burdamedia.pl (2018b). Retrieved from: https://www.burdamedia.pl/assets/mediakits/db20f551aa37ebeb8587296abdf8933c37188da0.pdf

Burdamedia.pl (2018a). Retrieved from: https://www.burdamedia.pl/magazyny/magazyn/37/National\%20Geographic\%20Traveler

Cohen, E. \& Cohen, S.A. (2012). Current sociological theories and issues in tourism. Annals of Tourism Research, vol. 39(no. 4), pp. 2177-2202. https://doi.org/10.1016/j.annals.2012.07.009

Drozdowska, M. \& Duda-Seifert, M. (2016). Turystyczne portale internetowe - wiarygodne źródło informacji. Turyzm, vol. 26(no. 2), pp. 7-14. http://dx.doi.org/10.18778/08675856.26.2.01

EA (2018). W ferie coraz częściej wyjeżdżamy do ciepłych krajów. W jakich krajach Polacy spędzają ferie najczęściej? Dziennikbaltycki.pl. Retrieved from: http://www.dziennikbaltycki.pl/turystyka/a/w-ferie-coraz-czesciej-wyjezdzamy-do-cieplychkrajow-w-jakich-krajach-polacy-spedzaja-ferie-najczesciej-wyjazdy-na-ferie, 12836254

Fodness, D. \& B. Murray (1998). A Typology of Tourism Information Search Strategies. Journal of Travel Research, vol. 37(no. 2), pp. 108-119. DOI: 10.1177/004728759803700202

Fursich E. \& Kavoori, A.P (2001). Mapping a critical framework for the study of travel journalism. International Journal of Cultural Studies, vol. 4(no. 2), pp. 149-171.

Gursoy, D. (2011). Destination Information Search Strategies. In: Wang, Y., Pizam, A. (eds.). Tourism Destination Marketing and Management: Collaborative Stratagies. Oxford, Cambridge: Cabi International, pp. 67-81. 10.1079/9781845937621.0067

Grupazpr (2018). Retrieved from: http://www.grupazpr.pl/marka/1039

Folker, H. (2010). The Dimensions of Travel Journalism. Journalism Studies, vol. 11(no. 1), pp. 68-82. https://doi.org/10.1080/14616700903290569

Hsu, C.H.C., \& Song, H. (2013). Destination image in travel magazines: A textual and pictorial analysis of Hong Kong and Macau. Journal of Vacation Marketing, vol. 19(no. 3), pp. 253-268.

Hsu, C.H.C. \& Song, H. (2014). A Visual Analysis of Destinations in Travel Magazines. Journal of Travel \& Tourism Marketing, vol. 31(no. 2), pp. 162-177. https://doi.org/10.1080/10548408.2014.873308

IAB Polska (2015). E-konsumenci - consumer journy online. Retrieved from: https://www.iab.org.pl/wp-content/uploads/2015/04/IABPolska_CJO2015_sport.pdf 
Johnson, S. \& de Lozano, C.A. (2002). The Art and Science of Magazine Cover Research, Journal of Magazine \& New Media Research, vol.5(no. 1 ). https://aejmcmagazine.arizona.edu/Journal/Fall2002/Johnson1.pdf

Jupowicz-Ginalska, A. (2017 a). Zadania okładek współczesnych magazynów drukowanych, Rocznik Bibliologiczno-Prasoznawczy, vol. 9 (no. 20), pp. 71-89.

Jupowicz-Ginalska, A. (2017 b). Tematy okładkowe polskich magazynów - elementy składowe i preferencje odbiorców. Kultura - Media - Teologia, vol. 28, pp. 196-205.

Kłopotowska, E. (2015). Czasopisma dla podróżników. Rynekprasowy.pl. Retrieved from: http://www.rynekprasowy.pl/czasopisma-dla-podroznikow/

Kruczek, Z. \& Walas, B. (2004). Promocja i informacja turystyczna. Kraków: Proksenia.

Lizzi, G., Cantoni, L. \& Inversini, A. (2011). When a Magazine Goes Online: A Case Study in the Tourism Field. In: Law, R., Fuchs, M. \& Ricci, F. (eds.). Information and Communication Technologies in Tourism 2011: Proceedings of the International Conference. 26-26 January, Vienna. Vienna: Springer Verlag.

McWha, M.R., Frost, W., Laing, J. \& Best, G. (2016). Writing for the anti-tourist? Imagining the contemporary travel magazine reader as an authentic experience seeker. Current Issues in Tourism, vol. 19(no. 1), pp. 85-99. https://doi.org/10.1080/13683500.2015.1013525

Mack, R.W., Blose, J.E. \& Pan B. (2007). Believe it or not: Credibility of blogs in tourism. Journal of Vacation Marketing, vol. 14(no. 2), pp. 133-144.

Marek, R. (2009). Determinanty rozwoju polskich biur podróży w Internecie. Warszawa: Promotor.

Molina, A. \& Esteban, A. (2006). Tourism brochures: Usefulness and image. Annals of Tourism Research, vol. 33(np. 4), pp. 1036-1056. https://doi.org/10.1016/j.annals.2006.05.003

National-geographic.pl (2018). Retrieved from: http://www.nationalgeographic.pl/magazines/traveler/2006/

Oniszczuk, Z. (2011). Mediatyzacja polityki i polityzacja mediów. Dwa wymiary wzajemnych relacji. Studia Medioznawcze, vol. 47(no. 4), pp. 11-22.

PBC (2018). Retrieved from: http://www.pbc.pl/rynek-prasowy/

PBC (2018). Retrieved from: http://www.pbc.pl/rynek-prasowy/raporty-pbc/miesieczniki/ Podroze.pl (2018). Retrieved from: http://podroze.se.pl/miesiecznik/covers/1/

Sarma, K.M, (2007). Influence of Information Sources on Tourists: A Segment-wise Analysis with Special Focus on Destination Image. Vision: The Journal of Business Perspective, vol. 11(no. 1), pp. 35-45.

Sumner D. E. \& Rhoades S. (2016). Magazines: A complete guide to the industry. New York: Peter Lang Publishing. 
Szypuła, G. (2017). Rośnie rola internetu w turystyce. Wp.pl. Retrieved from: http://turystyka.rp.pl/artykul/1344467.html

Teleskop.org.pl

(2018).

https://www.teleskop.org.pl/zkdp/index.jsp?p=publicDataNoReg

Retrieved

from:

Tjostheim, I., Tussyadiah, I.P. \& Hoem S.O. (2007). Combination of Information Sources in Travel Planning A Cross-national Study. In: Sigala, M., Mich, L. \& Murphy, J. (eds.). Information and Communication Technologies in Tourism. Vienna: Springer.https://doi.org/10.1007/978-3-211-69566-1_15

VMG PR (2014). Polska na wakacjach, czyli o promocji miejsc oczami turystów. Retrieved from:

https://swresearch.pl/pdf/Polska_na_wakacjach,_czyli_o_promocji_miejsc_oczami_turystow_ _raport

Vogt, C.A. \& Fesenmaier, D.R. (1998). Expanding the functional information search model. Annals of Tourism Research. Annals of Tourism Research, vol. 25(no. 3), pp. 551-578. DOI: 10.1016/S0160-7383(98)00010-3

Volo, S. (2010). Bloggers' reported tourist experiences: Their utility as a tourism data source and their effect on prospective tourists. Journal of Vacation Marketing, vol. 16(no. 4), pp. 297-311. DOI $10.1177 / 1356766710380884$

Wasike. B. (2017). Jocks versus jockettes: An analysis of the visual portrayal of male and female cover models on sports magazines. Journalism, pp. 1-18. DOI: 10.1177/1464884917716818

White, J.V. (1982). Designing for magazines. New York-London: R.R. Bowker Company.

Wolny, R. (2015). Internet jako źródło informacji e-konsumentów o ofercie handlowej i usługowej przedsiębiorstw. The Wroclaw School of Banking Research Journal, vol.15 (no. 3), pp. 413-414.

Woojin, L. \& Andereck, K. (2016). The Effect of Travel Magazine Features and Photos on Tourist Decision Making. Tourism Travel and Research Association: Advancing Tourism Research Globally. 5. http://scholarworks.umass.edu/ttra/2010/Visual/5

\section{Anna Jupowicz-Ginalska, Ph.D.}

Faculty of Journalism, Information and Book Studies

University of Warsaw

Bednarska 2/4, 00-310 Warsaw

www.wdib.uw.edu.pl

a.ginalska@uw.edu.pl

Anna Jupowicz-Ginalska specializes in media marketing. Her current scientific interests also include contemporary trends in marketing communication (especially the transmedia storytelling and multiscreening), VR, AR and pop culture. She is the author of numerous scientific publications on media marketing. For over 15 years she has been also professionally active in the 
practical sphere (in PR agencies and media corporations). 